\title{
Considering the this-worldly religious focus of the African traditional worldview as found in South Africa
}

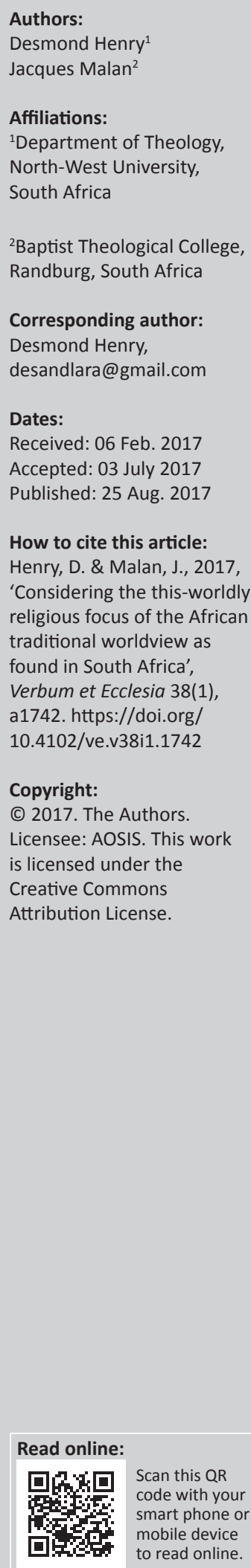

Most articles evaluating the African traditional worldview focus an attack on the ancestor cult or highlight positive aspects of the worldview. In either case, mention of the this-worldly religious focus tends to be 'in passing'. An evaluation of this aspect of the worldview is a gap in the research, which this article seeks to address. The findings should significantly affect evangelical ministry method to many people in the country. The this-worldly religious focus of the African traditional worldview as found in South Africa is considered. It is a focus which hardly, if ever, looks beyond this world and this age. The this-worldly focus is a significant feature of the African traditional worldview and related African Traditional Religion (ATR). The concern raised is that this feature of the worldview is prevalent in the country, is unbiblical and is a major problem affecting the church. The article first describes the this-worldly religious focus and how it is expressed in ATR and in those strongly influenced by ATR. It then discusses its prevalence in South Africa. Abiblical evaluation is then done, considering what the Bible has to say on the matter and considering the views of some evangelicals. Finally, some proposals are made for responding to the challenge. There are significant steps that can be taken to counteract the problem and so design evangelism and discipleship that the African believers are moved to resist rather than follow the this-worldly religious focus and so more faithfully follow the way of our Lord.

Intradisciplinary and/or interdisciplinary implications: Most articles evaluating the African traditional worldview focus an attack on the ancestor cult or highlight positive aspects of the worldview. In either case, mention of the this-worldly religious focus tend to be 'in passing' across the research spectrum. An evaluation of this aspect of the worldview is a gap in the research across many disciplines, which this article seeks to address. The findings should significantly affect evangelical ministry method to many people in the country working within these communities. This approach considers anthropological and Biblical insights in a compelling manner.

\section{Introduction}

A notable challenge to the Great Commission is the resistance of pre-missionary culture to Christian evangelism and discipleship. Making this challenge more complex is the fact that such culture sometimes welcomes certain aspects of Christianity, but resists others, thus producing an impure form of Christianity, which on the surface appears to thrive, but is not what it should be.

The African traditional worldview as found in South Africa is a case in point. It contains some unbiblical aspects. A significant one is its fear of the ancestors. Another is it is this-worldly religious focus. The latter is the focus of this article. It needs to be said that considering such unbiblical aspects is definitely not meant to put the entire worldview in a bad light. There is, however, the need to respond by seeking to lead people from the unbiblical way to the biblical way.

This article investigates the this-worldly religious focus of the African traditional worldview in South Africa, evaluates it and responds to it.

The investigation and evaluation are definitely necessary. If it shows African Traditional Religion (ATR) to be unbiblical and spiritually harmful, which it does, then ATR cannot be reconciled with biblical Christianity. Indeed, evangelism and discipleship among those affected by this thisworldly focus, would then need to include warning, teaching and guidance to the biblical position. Some practical steps are suggested in the last section.

\section{Christianity and the African traditional worldview}

Before looking at the this-worldly focus, we first take a broader look at the African traditional worldview and how biblical Christianity interacts with it. 
The African traditional worldview is deeply entrenched within the lives of many African people, regardless of their geographical location. With experience of ministry among the Dida Harrists in Ivory Coast, J.R. Krabill (1987) wrote the following significant words:

White folks come to Africa - they stay for a while, they kick up a lot of dust - and they go. But the traditions remain - deeply rooted, far beneath the dust, in the African soil. (p. 54)

A similar sentiment comes from the Africa Indigenous Church leaders, Ngada and Mofokeng (2001:17): 'We are Africans before being Christians. To deny our African-ness would be to forfeit our God-given lifestyle and to adopt an imposed culture'.

These quotes are rather striking. They are also disturbing, at least to Christian ministers who find some unbiblical features in the African traditional worldview. Christians cannot fully accept the insinuation that one cannot change his worldview because of our faith in God. Nevertheless, worldviews are not easily changed and to understand them well is a good first step in meeting the challenge. It will give one insight into the underlying motives and characteristic behavioural traits of a people (Henry 2010:105) and will guard against a superficial ministry which preaches Christ, but does not engage 'the underlying worldview' (Henry 2010:108).

What, then, is a worldview? James Sire (1977:17) calls it 'a set of presuppositions ... which we hold ... about the basic makeup of our world'. Yung (2007:438) says that it is the universe within which a people group lives and that it is foundational to people's values, shaping their culture. He adds that any threat to one's worldview 'will be unconsciously resisted' (Yung 2007:438). All people and people groups have a worldview and some of them overlap in various details. It has been found that there are many common elements in the worldviews of African groups, in South Africa and further north, so that one can legitimately refer to an African traditional worldview. A major part of this worldview is ATR. In fact, to a great extent, the two terms are interchangeable, because religion affects every part of their lives. Religious and secular aspects are integrated (Henry 2010:105).

The term 'traditional' is used, because the worldview has been passed down. Some Africans have moved away from their traditional worldview to some extent and have partly adopted another worldview. The African traditional worldview, however, is still very much alive in South Africa. Despite Christianity and Islam, ATR has not declined at all (Atta-Baffoe 2013:11).

Something that keeps ATR strong in the hearts of Africans is that even those who live in cities 'maintain personal contact with their rural homes' where ATR is strongest (Gehman 2005:6). Apart from that factor, there has been a resurgence of ATR in recent years, promoted by political action and the media. Many Africans seek to affirm their cultural and religious roots.
As mentioned earlier, one of the aspects of ATR is the thisworldly religious focus. That will now be discussed.

\section{The this-worldly religious focus}

The term 'this-worldly' is used by Müller (2013:317), Light (2012:135), Isichei (2004:318) and others. It focuses on the here and now rather than eternity. A person who does not believe in life after death will quite naturally have an exclusively this-worldly focus. There is a tension here in the sense that even biblical Christians do need to live and serve and do things in this world. On the other hand, our religion has a spiritual and eternal aspect that pervades our religious thinking. We are citizens of heaven (Phlp 3:20).

Even in the Christian church, there is tension between the this-worldly and the eternal or spiritual focus; more will be said of this later.

Reverting to the discussion of the African traditional worldview, it is notable that although there is belief in an afterlife and in spirits, their religious thinking tends to be very much more this-worldly than it should. Many writers say this explicitly. Shabangu (2005:186) states that for the traditional African, salvation is this-worldly. Bediako (1995:101) similarly writes that 'the stress in the primal religious worldview is decidedly this-worldly'. Vernon Light (2012:161) has come to the same conclusion: 'ATR is a thisworldly religion'.

Nothing brings out the this-worldly problem more than looking at one's main concept of salvation. The term allows such scope. A person can be saved from an embarrassment, an annoying visitor, a falling brick, an attacking army, guilt, the power of sin or eternal condemnation. As it turns out, ATR completely misses the eternal component.

\section{A description of how this religious focus is demonstrated in African Traditional Religion}

As in the case of the ancestor cult, the this-worldly religious focus touches many aspects of traditional African religious practice. This is not entirely unexpected. The African traditional worldview has very little concern for the future (Oosthuizen 1999:205). Thus, it is not too surprising that the African traditional focus would be on the here and now.

In our description, we will start by considering the prayers of those with the African traditional worldview.

\section{Prayers with a this-worldly focus}

Prayer is common among Africans in South Africa, both Christian and non-Christian. But what do traditional Africans pray for? Julius Muthengi (1998) writes:

The contents of prayers in African traditional worship is largely for material and physical blessing. Some of the main concerns are: protection from sickness and death, a long life, material prosperity, 
victory over enemies, protection from evil spirits, etc ... There does not seem to be any concern about the deity's will. (p. 254)

Christian Baëta of Ghana discovered the same thing. He compared the African-Initiated Churches (AICs) and the mission churches and found that a significant difference was what they prayed for; the former mainly prayed for health, children, employment, exams, protection, et cetera (Bediako 1995:65).

Yet another comment in the same line is one by Elizabeth Isichei (2004:318) who says that 'Neo traditional religion is ... insistently this-worldly. The devotee looks for answers to prayer in this life, not for compensation in a life to come'.

In Christian churches, there are many whose prayers focus on this-worldly concerns, but they are usually the less mature Christians, Christians in the Pentecostal churches and Christians from an ATR background. I have found that from personal experience of various prayer meetings through the years.

In 2016 an informal questionnaire was designed to gain insights regarding ministry to those with an African traditional worldview. The questionnaire was given to Christian leaders in various parts of South Africa ministering among the various language groups. One question posed was: 'Among those who pray, what do their prayers [the prayer of those understood to hold to the African traditional worldview] tend to focus on?' The answers in order of frequency were 'Health' (selected 11 times), 'Material needs' (selected 10 times), 'Protection' (selected twice) and 'God's kingdom' (never selected). The consistency of the answers from these leaders certainly served to confirm the thisworldly focus of the prayers of those in ATR.

\section{Healing stressed}

The great stress laid on healing is another expression of the this-worldly religious focus. Even finding employment or regaining a good relationship with the employer is considered as part of healing (Becken 1975:240) and thus salvation. In AICs, salvation from God is understood as holistic healing, touching both body and soul (Becken 1975:237). Nevertheless, physical healing is the most obvious understanding of healing, which is of major importance in ATR.

Shabangu (2005:155) notes that good health is seen as a key sign of blessing from the ancestors. 'Health, wholeness and wellbeing are integral to all forms of African religion' (Asamoah-Gyadu 2014:84). This is a general opinion. When writers describe aspects of ATR, healing always features prominently. The things which the typical African looks for in religion are physical healing, deliverance from demonic influence and the meeting of other basic needs (Anderson 1992:117). Whatever else might be listed, healing is there.

From ATR, the stress placed on healing naturally flows through to the AICs, which do more than other churches to accommodate ATR. Among the Zionists, 'Church founders were often healers rather than preachers ... It has been estimated that $80 \%$ of ZCC members joined the church after an experience of healing' (Isichei 2004:204). The latter is a remarkable statistic which indicates the very great stress on healing. K.A. Kubi bears that out by saying that 'the most important single reason why people join the Indigenous African Christian churches is healing' (Olowola 1998:289). Ndou (2000:167) writes that in the ZCC, physical healing is generally seen as more important than spiritual salvation. Health and healing are greatly stressed in ATR, which is why Zionist churches, where healing is more prominent than preaching in their Sunday services, is so popular (Niehaus 2009:316).

In the traditional African churches, 'salvation and healing are gifts that God gives his people here and now' (Ngada \& Mofokeng 2001:15). Some theologians like Müller (2013:317) see the link between present healing and salvation as very positive, an indication of a good integrated worldview, which should be commended. Limiting it to the here and now, however, is a disturbing matter.

\section{Family and community stressed}

Another aspect of the this-worldly religious focus is to limit one's vision to one's own people whom one knows here and now rather than God's eternal kingdom.

According to John Mbiti, Africans are traditionally anthropocentric and see man's interests as the purpose of everything (Otijele 1991:2f.). Shabangu (2005:204) agrees with Mbiti in saying that in ATR the greatest tragedy is to be cut off from the community. Even sin is defined in terms of harm to the community. Nürnberger (2007:62) even stated that if Christ does not punish sins against the community in this life, he 'will make no difference in Africa'. Indeed, even salvation itself is seen as community focused, as blessing on the community from all kinds of evils and dangers (Shabangu 2005:179).

\section{Blessing sought for in this life}

An important aspect of religion is whether one insists on blessing in this life or is content with 'mere' promises of blessing in the future life. The former tends to be true for those with an African traditional worldview. Cyril Okorocha says that Africans see salvation as that which makes the present life worthwhile (Collins 1993:43). They want the blessings to be visible in this life.

As a result of this desire, the traditional African is strongly drawn to the 'prosperity gospel', which stresses blessing in this life. Kuehl, Timothy and Luann, (the author interviewed this ZEMA missionary couple in Randfontein, pers. comm., March 2016) after working for 30 years among the Zionists in South Africa, say that the Africans tend to follow the prosperity gospel very much. Anderson (1992:6) agrees, adding that the Africans also find the Pentecostal churches 
attractive because of the emphasis on present spiritual experience.

Experience is stressed by those with a this-worldly focus, because it is the present life which is seen and felt. Byang Kato held that teachings of Black Theology are always referenced to human experience. Likewise, Basil Moore wrote that Black Theology 'is a situational theology' (Bediako 1999:394). Thus, a promise of blessing is not adequate to those with such a view.

In African churches, especially the AICs, this seeking of present blessing comes through from the African traditional worldview. Sibde Sempore noted how African churches tended to apply the Scriptures to seek blessings only in this life and warned against this tendency (Afan 2003:89). In the AICs, there is also a focus on the this-worldly benefits of church affiliation' (Daneel 1993:149). Africans join the churches to gain the this-worldly blessings.

The named focus naturally affects the way the traditional Africans in the AICs look at Christ. Unlike European Christians, African Christians tend to see Christ firstly as Provider (Chike 2008:230). To the traditional African, who Jesus is, is not as important as what he can do for them (Chike 2008:234). Even forgiveness is seen, not as removal of guilt, but as removal of a hindrance to provision (Chike 2008:236).

To be fair, it is true that many Christians without the African traditional worldview also seek blessings in this life. Nevertheless, there is usually a balance, with a good number of Christians seeking more blessing in the life to come.

\section{Answers sought for temporal dangers or problems}

Closely related to the above is the tendency of seeking answers for temporal rather than eternal dangers and problems.

Traditional Africans seek solutions to their life problems from the traditional healers and the AICs prophets. Those, in turn, go to the ancestors (Prill 2015:142). They seek answers to temporal dangers and life problems, not sin. The Old Testament, which often tells of salvation from such temporal enemies, appeals to people who are oppressed and suffering, which is why Black Theology prefers the Old Testament (Nicolson 1990:102f.). The traditional Africans also tend to make much of Christ's power over sickness, barrenness, blindness and demons (Chike 2008:227), all this-worldly problems.

\section{Sin and shame being man-focused}

A final aspect of the ATR this-worldly focus is the way sin and shame are conceived in a man-focused way. Nussbaum (1987:185) noted that the atonement, which was the main thing in the preaching of many missionaries, does not figure as the main thing in many independent church theologies'.
Ndou (2000:236) likewise discovered that the Vendas did not consider redemption from sins as important. More likely, the issue is that they conceive sin differently. Sin is seen as against people, not God, and as having immediate consequences in this life like barrenness, drought and sickness (Nürnberger 2007:61). ATR does not deal with sin against God (Light 2012:161) because that seems to have no significant thisworldly consequences.

Shame works the same way. Many people, but traditional Africans in particular, tend to fear shame more than God's wrath (Buys 2008:10). Interestingly, the one who reports a theft is commonly held as guiltier than the thief (Van der Walt 2005:2) because he causes shame before people.

Thus, sin and shame can be added to the list of aspects of the African traditional worldview, which demonstrate a thisworldly focus in their religious thinking.

\section{A gauging of the prevalence of this religious focus, its significance and the extent to which it tends to persist}

Having described the this-worldly religious focus of the African traditional worldview, it is a small step to noting its prevalence. Practically all the writers cited indicate that this focus is general and typical. It is ingrained in the worldview itself. Kwame Bediako, for example, wrote that the focus of ATR is this life with its concerns, cares and joys (AsamoahGyadu 2007:457). Crafford (1996) likewise gives a general description of ATR, saying:

Religion is thus primarily aimed at human happiness and prosperity within the person's own community here and now, rather than service of the supreme being or eternal bliss in the afterlife. (p. 11)

Thus the this-worldly focus is by no means exceptional in South Africa.

It is not only prevalent, but also significant. One rather practical effect is the way it influences biblical motivators. Because the African traditional worldview only considers this-worldly benefits, Isichei (2004:151) tells us, missionaries have found that the Africans, Zulus in particular, are not easily motivated by heaven, nor do they fear hell. Indeed, many do not even believe in heaven or hell (Maleke 2012:21). Mbiti (1970:259) wrote that no Africans traditionally believed in judgement in the hereafter, except two tribes which happen to be outside of South Africa. Thus, a significant biblical motivator falls away.

Another point of significance is that unbelief can easily hide in ATR. If only the here and now count, then faith, a key reality in evangelical Christianity, is almost irrelevant. Contrary to the Bible, those with the African traditional worldview cannot say with Paul: 'we walk by faith, not by sight' (2 Cor 5:7). 
Does the this-worldly focus persist when someone with an African traditional worldview joins a Christian church? It typically does, especially if the 'Christian' church is one of the AICs or one in which the Word of Faith movement is strong. The this-worldly focus in the AICs has been established by remarks and citations throughout the above discussion. What remains is to evaluate the focus biblically. The following section seeks to do that.

\section{A biblical evaluation of the this- worldly religious focus}

In this section the this-worldly religious focus is evaluated biblically. The Bible certainly says something on the subject under our consideration. Views of some evangelicals who have written on the subject are also brought into the discussion.

\section{Considerations from the references to creation at the start and end of the Bible}

As a starting point, the references to creation at the start and end of the Bible are considered. It is common convention to introduce the main theme at the beginning of a book and to stress it again at the end. The same principle is taught to theological students when they learn to construct a sermon. With that concept in mind, Christopher Wright (2010:48) points out that the Bible begins and ends with creation and believes that that should reflect the scope of our missions mandate. He adds that the final vision of the whole Bible is ... God coming down to live with us once again in a purged and restored creation' (Wright 2010:227). Since the creation is of this world, the reasoning is very relevant to this discussion.

Other Christian writers also present this line of thinking. Daneel (1993:166), for instance, commends churches which include agricultural projects in their approach to missions, which 'extends to all creation'. Howard Snyder wrote extensively on the application of salvation to creation. He writes that the Bible emphasises the restoration of creation more than it emphasises heaven (Snyder 2011:41). He says that the Bible teaches that 'Jesus will come to earth to redeem all creation' (Snyder 2011:61).

The above-cited writers are certainly correct in warning against ignoring our duty relating to this creation. Christians must not just attend church, evangelise and wait to escape to heaven.

On the other hand, the argument concerning the creation as a prominent theme at the start and end of the Bible, has weaknesses. The creation in Genesis stresses the Creator and man in God's image rather than the substance of the creation. Also true is that the creation in Revelation (references to a river, water, trees, leaves, fruit and light) is a new creation and highly symbolic of spiritual realities. It can be argued that the Bible uses concrete and familiar creation terms to speak to us about righteousness, life, truth, et cetera. Thus, the references to creation at the start and end of the Bible are not necessarily convincing evidence that the Bible supports a this-worldly religious focus.

Further Scriptures and biblical themes will now be considered, starting from the Old Testament.

\section{Considerations from the Old Testament}

The deliverance of the Jews from Egypt is mainly a thisworldly deliverance or salvation, although its value as a type (the technical term) will also be noted below. There are many Scriptures referring to it, but we quote just Exodus 6:6:

Therefore say to the children of Israel: 'I am the LORD; I will bring you out from under the burdens of the Egyptians, I will rescue you from their bondage, and I will redeem you with an outstretched arm and with great judgments'.

In the Exodus, God redeemed Israel. Wright (2010:101) correctly states that that redemption was political, economical, social and spiritual. It was partly this-worldly. Nicolson (1990:91) stresses the physical deliverance from slavery and believes that that is our cue to trust God for similar deliverance from present problems. He notes that the Old Testament type of salvation was from enemies, drought, barrenness and the like.

At the same time, we must note that the deliverance from Egypt is not only this-worldly. It was a type of deliverance from sin, that is, it powerfully points to and illustrates deliverance from spiritual bondage.

The Pentecostal churches, notably among the Africans, make a strong connection between physical and spiritual salvation. Asamoah-Gyadu (2007:456) points out that they get particular support for this connection from Hannah's words after the birth of Samuel. We quote 1 Samuel 2:1 and the last part of 2:5:

And Hannah prayed and said: 'My heart rejoices in the LORD; my horn is exalted in the LORD. I smile at my enemies, because I rejoice in Your salvation.... Even the barren has borne seven, and she who has many children has become feeble'.

From the context, it is clear that Hannah's joy came partly or mainly from God giving her a son. It appears that she regarded God giving her a son and removing her barrenness as 'salvation'. There are, however, reasons to believe that the poetic prayer is not simply Hannah giving thanks for the birth of her son. Baldwin (1988:55) notes that many take it as 'an existing hymn which Hannah made her own'. The fact that seven children are mentioned in verse 5 when Hannah had only one at the time, strengthens this argument.

Because the poem goes on to mention the king in verse 10, before the time of Israel's first king, Payne (1994:299) believes that Hannah's prayer was 'expanded', presumably by the author of 1 Samuel. Whichever way it is taken, it can be argued that Hannah did not necessarily see the removal of her barrenness as salvation, although it was probably part of her concept of salvation. Baldwin (1988:56) sees the term 
'salvation' in this prayer as firstly Hannah's personal experience in prayer answered and secondly with a broader application to Israel. This seems reasonable. Christopher Jero (2015:157), following R. Polzin, also see the application to Israel. He says that typology is the only reasonable explanation for the inclusion of some of the details (Jero (2015:158). All considered, it appears that the argument that this Scripture uses the term 'salvation' in a predominantly this-worldly sense is not strong.

There are many other examples of deliverances in the Old Testament which, at face value, are this-worldly. God delivered Israel repeatedly from military enemies in the times of the Judges and the time of the kings. Salvation in the Old Testament is undeniably this-worldly in many instances.

On the other hand, there are also many Old Testament texts that refer to spiritual deliverance from sin, an other-worldly matter. Psalm 32, Psalm 51 and Isaiah 53 are some of the better known passages that specifically refer to spiritual salvation from sin and guilt. Likewise, the entire sacrificial system regularly teaches on atonement and related spiritual concepts. The teaching on the Day of Atonement in Leviticus 16 is a notable example. The standard and surely correct understanding of the sin offering on the Day of Atonement is expressed by Benjamin Ribbens (2011:90) as 'a Christological type of Christ's death'. The focus is on the forgiveness of sin and relationship with God. To miss these truths is to miss the heart of the matter. The spiritual sin-related concept of salvation is very significant in the Old Testament.

The idea of a future salvation and salvation relating to the afterlife, however, was not expressed as a prominent theme in the Old Testament. That became more prominent in the exilic and post-exilic period (Nicolson 1990:92). It also continued in the New Testament, which will be considered next.

\section{Considerations from the New Testament}

The New Testament starts with the coming of Christ into the world and his name means 'Saviour'. We quote a verse from the very first chapter, Matthew 1:21:

And she will bring forth a Son, and you shall call His name JESUS, for He will save His people from their sins.

This verse leaves the reader in no doubt as to what the saving is from. The same idea is conveyed throughout the New Testament (e.g. Mt 26:28; Rm 3:21-26; Eph 1:7; 1 Tim 1:15). Although Jesus saves from some other things, he came primarily to save from sin. Even Nicolson (1990:98) admits that, in the New Testament, the concept of salvation changed from its main Old Testament meaning, becoming more a personal salvation from sinfulness. Similarly, Kato claims quite rightly that the freedom which Christ gives is primarily from sin (Prill 2015:154). Nürnberger (2007:60), amazingly, considers even the New Testament concept of salvation to be mainly this-worldly. He holds that Christians have too much of a 'spiritualised concept of salvation'. The criticism is unreasonable, because the
New Testament, especially in the letters, presents salvation as an almost entirely spiritual concept.

In some New Testament passages, we are definitely instructed to focus on spiritual and eternal things, rather than on what is temporal and earthly. In the Gospels, for instance, we find Jesus telling the parable of the Sower (Mt 13, Mk 4 \& Lk 8). The thorny soil indicates an excessive interest and concern for things of this world. In the end, the plant is choked and bears no fruit. Rankin and Stetzer (2010:66) remark concerning such believers that 'Satan devours those who follow Christ for the wrong reasons'. There is nothing spiritual about following Christ for this-worldly benefits.

More direct teaching on this matter is given in 1 John 2:15. There we are told: 'Do not love the world or the things in the world.' Another passage that directs the Christian away from a this-worldly focus is Colossians 1:1-2:

If then you were raised with Christ, seek those things which are above, where Christ is, sitting at the right hand of God. Set your mind on things above, not on things on the earth.

Later in the same chapter, some verses seem to support a thisworldly concept of salvation. We quote, in part, Colossians 1:16-20:

For by Him [Christ] all things were created that are in heaven and that are on earth, visible and invisible ... For it pleased the Father that in Him all the fullness should dwell, and by Him to reconcile all things to Himself, by Him, whether things on earth or things in heaven, having made peace through the blood of His cross.

Wright (2010:59) concludes that, because Christ reconciled everything, humans and the rest of creation, to himself through the blood of the cross, the cross applies wider than human spiritual redemption. Snyder (2011:139), commenting on the same Scripture says that our worldview must include the expectation of the restoration of all things through the cross of Christ. He (Snyder 2011) adds, less cautiously I believe:

It is absurd to think that Jesus died and rose again to save our souls - not our bodies and the whole creation. Why should Jesus rise physically to save us only spiritually?... Would Jesus' incarnation really have been necessary if God wanted to save only our souls? (p. 226)

A different perspective is that of F.F. Bruce. He writes that the reconciling cannot be in the full sense of saving; otherwise, even demons and all people would be saved, which would contradict other Scriptures (Bruce 1984:75). Rather, everyone and everything will be gathered together in subjection to Christ, all active opposition broken. Even Christ's enemies would submit, but not willingly (Bruce 1984:76). His death on the cross placed Christ in that position of authority. Thus, the work on the cross affected all of creation and elect people in particular, as is conveyed in verses 21 and 22 (Bruce 1984:74). Bruce's reasoning is convincing. It seems that this passage does not call Christians to see this world's things as objects of Christ's saving work with corresponding efforts and prayers expected of them. 
Is the New Testament salvation a this-worldly salvation and does the New Testament call us to place religious focus on this world? As has been indicated, it rather keeps pointing us away from this world. Matthew 6:33, for instance, puts the spread of God's kingdom as a human priority above temporal human needs (McGavran 1980:43). Added to this, we know that God's kingdom is 'not of this world' (Jn 18:36). As it says in Hebrews 13:14: 'here we have no continuing city, but we seek the one to come'.

Although present deliverance in a this-worldly sense appears to be conveyed in some passages, especially the healing passages, the New Testament as a whole sees salvation not as this-worldly, but as spiritual deliverance from sin and final judgement. Considering the whole Bible, Vernon Light (2012:135) concludes, I believe rightly, that salvation is primarily spiritual.

\section{The biblical correlation between healing and salvation}

The New Testament healings seem to have a definite thisworldly aspect that needs to be considered. Judging by the New Testament record, most of the miracles performed by Jesus and the apostles were physical healings. It is also clear that physical healing plays a very important part in all forms of ATR.

Now there are probably three purposes for the New Testament healings. One is to authenticate the authority of the messenger and his message. The healings point to the fact that the messenger is from God and his message ought to be taken seriously. A second purpose is for illustration or teaching. A leper is 'cleansed', alluding to spiritual cleansing. A blind man in John 9 is given sight, introducing some teaching about spiritual blindness and spiritual sight. Trapnell (1996:453) only gives these two purposes, implying that they are the only ones. A third purpose, however, is to show compassion. Matthew 20:34 says in connection with two blind men: 'Jesus had compassion and touched their eyes. And immediately their eyes received sight.'

Those who have a this-worldly focus will naturally emphasise the third purpose, namely to show compassion, making God's desire to relieve temporal suffering more significant than his desire to spiritually save people from sin and hell. Others tend to view physical and spiritual healing as equally important.

Barends (1993:282) believes that the healing ministry of Christ and ATR are similar in being integrated and holistic, touching physical, social and spiritual healing, where forgiveness, confession of sins, restoration of relationships and physical healing are related. He believes that Christians should apply the same integrated approach (Barends 1993:285). Similarly, Daneel (1993:153) says that the AICs are justified in viewing salvation as healing and protection in this life rather than merely spiritual redemption because it shows a more comprehensive interpretation of salvation.
Falk (1979:447) says that the Church in Africa 'has considered healing the sick and helping the needy as an integral part of its redemptive ministry' and claims that to ignore health needs would be a denial of the faith (Falk 1979:451).

Ngada and Mofokeng (2001) have a similar perspective when they say that:

The Christianity brought by the missionaries divorced the salvation of the soul from the salvation, or healing, of the body. The healing of a sick society was not even considered. The focus was on saving souls from hell. (p. 35)

I found the authors of this book unfairly negative about the missionaries and I have good reason to doubt their allegation that the missionaries were unconcerned about health problems. Having read some biographies of missionaries who laboured in Southern Africa, their allegation does not hold. Nevertheless, they did focus more on spiritual salvation.

Another argument relating New Testament salvation with physical healing simply points to James 5:15. That is quoted here and considered:

And the prayer of faith will save the sick, and the Lord will raise him up. And if he has committed sins, he will be forgiven.

In this verse, the term 'save' is used for healing (Becken 1975:242). It also indicates that the healing of the body and of the soul are sometimes related. Nevertheless, it is not always related, as is indicated by the word 'if' (King 1967:122). There is also not always a direct connection between sin and sickness (Kistemaker 1986:176). Neither here nor elsewhere in the New Testament is physical healing equated with spiritual healing or made to equal it in importance. Indeed, when a true Christian reads through the New Testament, the importance of forgiveness clearly stands out far above that of physical healing.

A profound statement by John Piper (2003:211) captures the limitation of a this-worldly focus on physical healing and a relatively small interest in spiritual healing: 'It is natural to hate pain ... It is supernatural to hate sin'. The New Testament perspective is that physical healing is usually a good thing and can be given by God, but true salvation is spiritual, is eternal, deals with sin, and is of much greater importance. This is because the soul is eternal, while the body is temporary. This truth is captured in Jesus' words of Matthew 10:28: 'Do not fear those who kill the body but cannot kill the soul'. It is also conveyed by the way Jesus, in Mark 2, first forgave the paralytic's sins and then healed his body.

In summary, the New Testament healings probably do not have this-worldly concerns as the primary purpose and, when bodily healing is compared with salvation for the soul, the latter is indicated as more important. To ignore the spiritual would clearly be unacceptable. 


\section{The importance of spiritual word ministry in the broader context of Christian ministry}

Let us move from healing to ministry in general. Clearly, if Christians are strongly influenced by ATR, with its thisworldly character, their idea of ministry will follow suit. On the continuum of ministry approaches indicated in Table 1, their approach would be very close to ' $\mathrm{D}$ '.

We will briefly comment on the first three approaches.

Approach A: The Lausanne II manifesto states that 'Good news and good works are inseparable ... True mission should always be incarnational' (Coote 1990:13). That is quite biblical. The same Bible which commands evangelism and preaching commands helping the needy. Flip Buys rightly says that justice and justification by faith, worship and political action, the spiritual and the material, personal change and structural change belong together' (Logan 2013:93). The social and spiritual mandate of the church (Bosch 2006:505) are both biblical. The missiologist Newbigin (1984:149) stressed, quite rightly, that the gospel itself insists on social action, healing and teaching and he held that it was good that many Christian bodies that were at first exclusively committed to evangelism later got involved in those other ministries. Evangelism and preaching are biblical, but complete neglect of other ministry to the world is not.

Approach B: This approach holds that, although many thisworldly ministry activities are needed, the eternal or spiritual ministry activities are most essential and need to take priority. Grudem (1994:868), for instance, notes that there are deeds which should 'adorn the gospel' (Tit 2:10), like social action, but such action should not replace evangelism as 'the primary ministry that the church has toward the world'. Beyerhaus (2013:7), likewise, supports the doing of works of love in response to present needs, but is concerned about the 'massive shift of priority from preaching to social responsibility'. He is concerned that missions must avoid replacing eternal salvation with temporal well-being as if Christ's kingdom is only of this world (Beyerhaus 2013:11).

As has been mentioned, salvation can biblically be seen as deliverance from various evils (Modiboa 2005:25f.; Shabangu 2005:182), but the New Testament and Christian understanding is narrower-salvation is spiritual deliverance from sin and Satan. Ultimately, New Testament salvation is other-worldly (Nicolson 1990:100) and, therefore, ministry focus should likewise be other-worldly. The preaching of the gospel and the need for the new birth and conversion are prominent in the New Testament and must also be in our ministry. A number of evangelical scholars have noted this and emphasised the need to give such spiritual ministry the

TABLE 1: Continuum of ministry approaches.

\begin{tabular}{llll}
\hline A: Other-worldly & B & C & D: This-worldly \\
\hline Only evangelism & Meeting all kinds & Meeting all kinds of & Humanitarian \\
and preaching; & of needs, but & needs, without & ministry only; \\
complete neglect of & giving priority to & prioritising spiritual & complete neglect of \\
humanitarian needs & spiritual needs & needs & spiritual needs \\
\hline
\end{tabular}

focus. Coleman (1986:137) writes with concern that 'Many churchmen have such an all-inclusive view of discipleship that the specific work of rescuing perishing souls from hell scarcely receives attention'. According to Donald McGavran, evangelism is the key to a more just and peaceful world, because 'church growth should result in improvements in the social, economic and political realms' (Fung 1992:183). Thus, he gives evangelism the priority. According to him, the biggest help to social justice is many people becoming truly Christian.

The World Council of Churches (WCC) tries to make the world a better place regardless of whether they are true Christians or not, but mission should essentially be 'those activities that multiply churches, that win the lost, that disciple unreached peoples' (McGavran 1986:58). The social side of Christian witness is not the actual gospel, nor is it the reason the Lord sends out missionaries. From the New Testament, it is clear that the gospel is mainly about spiritual regeneration, forgiveness, justification and eternal life. As Shields (1998:92) points out, the apostles were not sent to improve housing, educate, campaign for a better government, et cetera.

In 1982 John Stott led a consultation on the relationship between evangelism and social responsibility. The consultation produced a document including the following: 'Evangelism and social responsibility ... are integrally related ... The partnership is, in reality, a marriage ... In the church's mission of sacrificial service evangelism is primary' (Wright 2010:276). From the commitment that concluded the third Lausanne Congress on World Evangelisation in 2010 are the words:

Let us keep evangelism at the centre of the fully integrated scope of all our mission, inasmuch as the gospel itself is the source, content and authority of all biblically valid mission. (Johnstone 2011:239)

This appears to be the biblical view.

Approach C: The trend in missions is towards the right in the continuum. This is especially seen in social justice issues taking priority. Projects for economic or social improvement are taking priority over evangelistic preaching; the improvement of economic and social conditions is taking priority over the salvation of souls (Beyerhaus 2013:4). This position is sometimes called the social gospel. Flip Buys writes that 'the social gospel concentrates not so much on individual salvation of one's own soul, but rather on the "evangelisation" and "conversion" of social structures and institutions' (Logan 2013:91). Although good and right in itself, it ends up channelling resources away from real church growth towards social and material improvement (McGavran 1980:308). It is the view which the WCC tends to support, promoting a kind of socialist utopian ideology at the expense of the saving of souls (Scarborough 2013:2). The international move in that direction became evident from the 1980s. An international evangelical conference in Wheaton in 1983 refrained from giving evangelism priority over social concerns (Bosch 2006:510), a priority which had been expressed in earlier 
conferences. David Bosch (2006:507) agrees with this trend and criticises Billy Graham and Donald McGavran for seeing the primary missionary task as evangelism and the secondary fruit as social involvement. Beyerhaus (2013:5) claims that, contrary to the Bible, such so-called 'transformational theology' underplays what Christ has done for us and stresses what we must do for society. He says it sees its task as building an earthly kingdom of God (Beyerhaus 2013:6).

This brief discussion does not completely settle the debate nor prove the priority of the spiritual aspect of Christian ministry. Nevertheless, it serves to remind us of some of the issues involved and highlights the concern of many that the ministry of proclaiming the truth should be given special priority and not be swallowed up by our other necessary Christian ministry. It also points to the need to guard against the slide towards neglecting spiritual, other-worldly ministry, as is inevitable by Christians who retain an ATR worldview.

\section{The biblical perspective on guilt, shame and judgement}

The African traditional worldview has a strong sense of shame towards people and a poor sense of guilt. The big motivators in ATR are shame and fear. According to Buys (2008:6), Africans are shame orientated, in contrast to the guilt orientation of Westerners, although there is always a bit of both. In other words, they are moved more by a concern that they will be put to shame in this life than by a concern that they are guilty and will be brought to justice. Buys (2008:10) holds that Christ both paid our debts and covered our shame on the cross. This, however, is only true if that shame is shame before God. There is a big difference between shame before people (a this-worldly concept) and shame before God. Christians often have to bear shame before people even for doing what is right. Galatians 5:11 speaks of the 'offence of the cross' and Hebrews 13:13 calls us to bear Christ's reproach. In both cases, it involves shame before people, which Christ did not remove. What the cross of Christ does remove is shame and guilt before God.

Those with a this-worldly focus sometimes take the matter further. Nicolson (1990:216) holds that salvation from sin and guilt are not very relevant to a person who is oppressed, has inadequate accommodation, has inadequate education and is living in poor social circumstances. What is more, his sins of sexual immorality, violence and theft are the result of his living conditions and not really his fault. The sins against him are more relevant than his own sins (Nicolson 1990:112). There is painful reality in these words. This-worldly suffering can make one's felt need for spiritual salvation less. Nevertheless, the ultimate tragedy is not temporal suffering, but to die in one's sins (Jn 8:24). When the Holy Spirit opens the heart of a sinner, he usually starts by confronting own sin and causing the person to seek salvation in Christ (De Vries 2015:5). Any ministry claiming the working of the Holy Spirit which does not produce conviction of sin or does not mainly focus on the biblical Christ should be questioned (De Vries 2015:6). If ministry is to be biblical, it needs to call all people to repentance from sin, as John the Baptist, Jesus and Peter did. Sin and guilt before God must be dealt with as more serious even than severe temporal suffering.

We have already noted the weak sense of the future in the African traditional worldview. This naturally leads them to see judgement in this life only. Future judgement and hell, however, are realities warned about in Scripture. Especially Jesus' words in the Gospels bring out the warnings, notably in the parables. 2 Peter 3 and Revelation 14 and 20 are some clear warnings of future judgement. Taylor (1986) writes that:

To bring a more just society, and raise the living standard of oppressed people, without also giving them a basis for forgiveness, true peace, and everlasting life, would leave people still in bondage to sin and hell. (p. 71)

That would not be valuable. Final future judgement is appointed for people (Heb 9:27). In removing the warning of future judgement, the this-worldly religious focus is, therefore, unbiblical.

\section{The man-centred rather than God-centred result of a this-worldly religious focus}

As a final subsection in this biblical evaluation, we consider the man-centred focus. A this-worldly focus quite naturally becomes man-centred. It focuses on blessings that man can get now, relief for man from current problems, protection for man from this-worldly dangers and misfortunes, et cetera. Some of this is inevitable. But what must our evaluation be when it is the exclusive or almost exclusive focus of ATR, which is what it is? This is considered here.

Rankin and Stetzer (2010:21) write that the glory of God demands that we do not become self-centred, focused on our own blessings and relationship with God', and yet that is exactly what ATR is. It is in stark contrast to the biblical position. The biblical gospel is about God, in Christ, redeeming sinners for himself. This is conveyed clearly in passages like Revelation 5:9. Note especially the words 'redeemed us to God':

And they sang a new song, saying: 'You are worthy to take the scroll, and to open its seals; for You were slain, and have redeemed us to God by Your blood out of every tribe and tongue and people and nation'.

Another Scripture which highlights the required God-centred focus is Romans 11:36: 'For of Him and through Him and to Him are all things, to whom be glory forever. Amen'. Man's greatest need is met by him looking to Christ and God. Man's highest calling is to be God-centred in his priorities, desires and thoughts.

Many would want to balance this consideration. Vernon Light (2012), for example writes:

A Gospel that does not speak to one's total needs - e.g. need for work, education, food, housing, clothes, clean water, respect, and love - is surely no Gospel ... More church leaders in Africa 
need to be trained in holistic ministry if the Gospel is to have any credibility. (p. 352)

Light has written an excellent book on ATR from which the above quote comes. Christianity certainly needs to be holistic and it must touch all aspects of life. A concern which is probably legitimate, however, is that the term 'holistic' tends to be centred around the this-worldly needs of man. Light is right that the gospel must touch these needs and that credibility is gained by doing so, but maybe the gospel itself only touches them in an indirect way. The Scriptures make it clear that both the gospel and our lives must be God-centred. Schutz (2009:300) is surely correct with his God-centred gospel perspective when he writes: 'A gospel that begins with me and ends with me is no gospel at all ... the gospel begins with God and is for God'. The teaching of Matthew 6:33 is precisely that when people are God-centred in what they seek in life, God will care for them even in temporal ways.

If our religious focus is man-centred, it falls short of the biblical way for Christians.

\section{Concluding the evaluation}

We have been considering the this-worldly religious focus of the African traditional worldview as found among many in South Africa. It was described in its various expressions. Its prevalence was then gauged. After that it was evaluated by measuring it up against the Scriptures and with some discussion from evangelical Christians. The finding is that ATR's almost exclusively this-worldly religious focus is unbiblical. Thus, it must concern biblical Christians, especially those in ministry in South Africa. The concern is that many Africans mix ATR's this-worldly focus with Christianity, and many churches appear to accommodate this unbiblical aspect. No doubt, it is displeasing to the Lord and is seriously weakening his church.

\section{Addressing the problem of the this- worldly religious focus}

Christians ministering to Africans influenced by the African traditional worldview need to design their evangelistic and discipleship ministry so as to strongly discourage the unbiblical focus that we have been investigating.

\section{Some difficulties in addressing the problem}

At the outset, the difficulties in dealing with this matter must be stated. One difficulty is that the unbiblical aspect is not very clear-cut. It is only a problem if there is too much or an exclusive focus on this-worldly matters.

Another difficulty is that the people with an African traditional worldview are naturally drawn to this-worldly benefits and will be repelled by a ministry which warns against the focus. Fung (1992:92) writes that 'quantitatively, the number one means of evangelism today is probably faith healing'. People seek healing, find it in a church, and become Christians. Thus, efforts to move people away from this excessive focus will be going against the tide, as it were.

A third difficulty is that there is a Christian duty of providing the needy with this-worldly help, but such help will probably reinforce their this-worldly focus. Such a ministry is likely to produce Christians who look for earthly rewards, sometimes called 'rice Christians'. On the other hand, we have to provide in time of need, sickness and bereavement as far as possible to keep the people from going to ATR to meet their needs (Gehman 1999:210f.) and to follow the example of Christ and the early church.

\section{Some guiding principles in addressing the this-worldly focus}

How then should the problem of the this-worldly focus be addressed, in spite of the difficulties mentioned? Here are a few guiding principles.

Lovingly provide without reinforcing a this-worldly focus: Christians do need to meet temporal needs. This care must be practical and include this-worldly provision. It must include support in times of crisis and prayers for the temporal needs of the people. At the same time, we must carefully avoid making a focus of the this-worldly benefits and the eternal and spiritual matters must very deliberately be emphasised in the ministry. They are the primary benefits in the Christian faith. We must never make the temporal things the focus of ministry, as typical AIC ministries and many others do.

Be God-centred in ministry: The evangelistic ministry must be deliberately God-centred. Reisinger (1982:47) rightly points out that a God-centred gospel shows that we understand conversion to be a work of the Holy Spirit, not human manipulation. Man-centred evangelism would naturally fail to make men God-centred in their thoughts and God-fearing in their hearts (Reisinger 1982:140).

Aim at making true disciples: The evangelism must be thorough and make people God-pleasing rather than just happy. A superficial gospel that underplays repentance and commitment must be avoided as hindering rather than helping our purpose. The aim must be to make genuine disciples who are moving towards greater spiritual maturity.

Stress the spiritual benefits of the gospel: We must beware of accommodation in evangelism, emphasising secondary benefits of the gospel while bypassing the main issues (McCloskey 1995:37). We should deliberately emphasise the primary benefits of the gospel, which are eternal and spiritual things.

Stress the universal Church rather than denominations and local communities: We have noted how one expression of the this-worldly focus is being concerned only with one's own people or community. An antidote is to emphasise to converts that they are becoming God's people and to 
emphasise that, more than denominational membership (Nussbaum 1987:186).

Spend time with the people: We need to spend time with the people, going to their homes and churches, mixing with them and having fellowship together. This is vital, because of their community focus. It is a valuable expression of love, without being this-worldly.

Teach the Bible and how to interpret it: The Bible must be the primary content that we teach. Obviously, biblical teaching will move one's worldview from unbiblical to biblical. The content, however, must not just be from the Bible, but be the Bible itself. There must be interaction with its actual words. Together with this, we must carefully teach on how to use and interpret the Bible, keeping in mind the tendency to certain common hermeneutical errors. A notable one is to view the Bible or its contents as magical instead of as true communication from God. Another notable error to lead them away from is to read passages in an over-simplistic way without giving thought to their context (literary, historical or redemption-historical). This error is responsible for much of the this-worldly focus among Christians.

Teach a right view on sin: As to sin, our teaching must show how its main aspect is God-ward (Ps 51:4), and not primarily against fellow men. We should also warn that sin can make a person more open to demon activity. We must teach that sin must be confessed and forsaken and that salvation in Christ brings true and complete forgiveness in the God-ward aspect.

Teach on prayer: We should encourage converts by teaching and example to pray more for spiritual matters of God's kingdom and less for this-worldly needs.

Make good use of festivals: We should make good use of Easter, weddings and other special occasions and community events to strengthen biblical values and teach biblical themes. ATR has many festivals and the African traditional way of thinking learns much better through symbols and doing than through lecture-style teaching. Use them to reinforce the biblical worldview. These festivals are likely to become ongoing customs with ongoing value.

There are certainly many other practical principles that could be applied to help move those who hold onto an excessively this-worldly religious focus stemming from the African traditional worldview to a more biblical position. Nevertheless, the above is likely to be a significant help.

\section{Conclusion}

The African traditional worldview in South Africa is a complex set of ways and traditions involving ways of thinking, believing and behaving. The religious aspects of this particular worldview are so integrated into every other part that the terms ATR and African traditional worldview are practically interchangeable. The African traditional worldview has both commendable and unbiblical elements.
The latter is a concern, especially because the worldview is still very influential and prominent in South Africa. The African traditional worldview is often diluted, especially in the cities, but it remains well-established and keeps its hold on many. This hold typically continues even after the adherents join Christian churches. Thus, a form of syncretism is extremely common or the adherent lives in two worlds, following Christian ways some of the time, but reverting to ATR in times of crisis.

One significant aspect of the African traditional worldview is the almost exclusively this-worldly religious focus. It is difficult to evaluate because some attention needs to be given to this-worldly matters and because many people who are not influenced by ATR have a similar religious focus. Nevertheless, the evaluation was done. The this-worldly focus was measured up against the Old Testament, the New Testament and various biblical considerations and found to be a serious error. It needs to be opposed and people need to be moved away from it.

The crucial matter of how to conduct evangelistic and discipleship ministry to bring those from an ATR background to Christ and from the this-worldly focus to the biblical position was considered. Various sources were consulted, especially by evangelical authors who share the concerns expressed in this study and some ministry principles were proposed.

The author believes that the this-worldly religious focus of the African traditional worldview is having a very harmful influence on many Africans in South Africa, even in Christian churches. May evangelical ministers in this country awake to the problem and may the Lord Jesus Christ enable his church to meet the challenge of leading many to the corresponding biblical faith and practice! To him be the glory!

\section{Acknowledgements Competing interests}

The authors declare that they have no financial or personal relationships that may have inappropriately influenced them in writing this article.

\section{Authors' contributions}

The article has arisen from J.M.'s Master's degree, which was supervised by D.H. at the Baptist Theological College of Southern Africa.

\section{References}

Afan, M., 2003, 'Sidbe Sempore: Spiritual itinerary of an African theologian', in B. Bujo \& J. Muya (eds.), African theology in the 21st century: The contribution of the pioneers, n.p., Pauline's Publications Africa, Nairobi, Kenya.

Anderson, A., 1992, Bazalwane: African Pentecostals in South Africa, UNISA, Pretoria. Asamoah-Gyadu, J.K., 2007, 'Broken calabashes and covenants of fruitfulness: Cursing barrenness in contemporary African Christianity', Journal of Religion in Africa 37(4), 437-460. https://doi.org/10.1163/157006607X230535

Asamoah-Gyadu, J.K., 2014, 'Therapeutic strategies in African religions: Health, herbal medicines and indigenous Christian spirituality', Studies in World Christianity 20(1), 70-90. https://doi.org/10.3366/swc.2014.0072 
Atta-Baffoe, V., 2013, 'African traditional religion', in J. Corrie (ed.), Dictionary of mission theology, pp. 10-12, IVP, Nottingham.

Baldwin, J., 1988, 1 and 2 Samuel: An introduction and commentary, IVP, Leicester. (Tyndale Old Testament Commentary Series).

Becken, H.-J., 1975, 'Healing in the African independent churches', Lutheran Quarterly 27, 182-210. https://doi.org/10.2143/SID.15.2.2004104

Bediako, K., 1995, Christianity in Africa: The renewal of a non-western religion, Orbis, Edinburgh.

Bediako, K., 1999, Theology and identity: The impact of culture upon Christian though in the second century and in modern Africa, Regnum, Oxford.

Beyerhaus, P., 2013, World evangelization or world transformation? transl. D. Scarborough, International Christian Network, Cape Town.

Bosch, D., 2006, Transforming mission: Paradigm shift in theology of mission, Centre for Contemporary Christianity, Bangalore.

Bruce, F.F., 1984, The epistles to the Colossians, to Philemon, and to the Ephesians, Eerdmans, Grand Rapids, MI.

Buys, P.J., 2008, 'Shame, guilt and HIV/AIDS in rural communities', Practical Theology in South Africa 23(3), 1-14, Repaginated.

Chike, C., 2008, 'Proudly African, proudly Christian: The roots of Christologies in the African worldview', Black Theology 6(2), 221-240. https://doi.org/10.1558/ blth2008v6i2.221

Coleman, R.E., 1986, 'The great commission life-style', in R.E. Coleman (ed.) Evangelism on the cutting edge, pp. 127-141, Fleming H Revell, Old Tappen, NJ.

Collins, T., 1993, 'Review of Okorocha Cyril 1987, The meaning of religious conversion in Africa', Ogbomoso Journal of Theology.

Coote, R., 1990, 'Lausanne II and world evangelization', International Bulletin of Missionary Research 14(1), n.p.

Crafford, D., 1996, 'African traditional religions', in P. Meiring (ed.), A world of religions: A South African perspective, pp. 1-26, Kagiso, Pretoria.

Daneel, M.L., 1993, 'African independent church pneumatology and the salvation of all creation', International Review of Mission 82(326), 143-166. https://doi. org/10.1111/j.1758-6631.1993.tb02659.x

De Vries, B.A., 2015, 'Divine empowerment: The Holy Spirit and church revitalisation' Die Skriflig 49(1), Article 1955, 1-8. https://doi.org/10.4102/ids.v49i1.1955

Falk, P., 1979, The growth of the church in Africa, Zondervan, Grand Rapids, MI.

Gehman, R.J., 1999, Who are the living-dead? A theology of death, life after death and the living-dead, Evangel, Nairobi, Kenya.

Gehman, R.J., 2005, African traditional religion in biblical perspective, rev., East African Educational, Nairobi.

Grudem, W., 1994, Systematic theology: An introduction to biblical doctrine, IVP, Leicester.

Henry, D., 2010, 'The challenges of an afro-centric ecclesiology in missiological perspective', The South African Baptist Journal of Theology 19, 104-115.

Isichei, E., 2004, The religious traditions of Africa: A history, Praeger, Westport.

Jero, C., 2015, 'Mother-child narratives and the Kingdom of God: Authorial use of typology as an interpretive device in Samuel-Kings', Bulletin for Biblical Research 25(2), 155-169.

Johnstone, P., 2011, Future of the global church, Authentic Media, Milton Keynes.

King, G.H., 1967, A belief that behaves: An expositional study of the epistle of James, Christian Literature Crusade, Fort Washington, MD.

Kistemaker, S.J., 1986, Exposition of the epistles of James and the epistles of John Evangelical Press, Hertfordshire.

Krabill, J.R., 1987, 'Ministry among the Dida Harrists of Cote d'Ivoire: A case study', in D.A. Shank (ed.). Ministry of Missions to African Independent Churches: Papers Presented at the Conference on Ministry to AICs, pp. 14-19, Abidjan, Cote d'Ivoire, July 1986, Mennonite Board of Missions, Elkhart.

Light, V.E., 2012, Transforming the church in Africa: A new contextually-relevant discipleship model, AuthorHouse, Bloomingham. (Author from SATS).

Logan, S.T. (ed.), 2013, Reformed means missional: Following Jesus into the world, New Growth, Greensboro, NC.

Maleke, I., 2012, Study guide for African spirituality, Mukhanyo Theological College, KwaMhlanga.

Mbiti, J.S., 1970, Concepts of God in Africa, SPCK, London.

McCloskey, M., 1995, Tell it often - Tell it well: Making the most of witnessing opportunities, Thomas Nelson, Nashville.

McGavran, D., 1980, Understanding church growth, Eerdmans, Grand Rapids, MI.
McGavran, D., 1986, 'My pilgrimage in mission', International Bulletin of Missionary Research 10(2), n.p.

Modiboa, B.J., 2005, 'The confusion in understanding salvation in Christian religion by African Christian people as it relates to Salvation in ATR Hampers the building up of the local church', MTh thesis, University of Pretoria.

Müller, R., 2013, "The "Indiginizing" and "Pilgrim" principles of Andrew F Walls reassessed from a South African perspective', Theology Today 70(3), 311-322. https://doi.org/10.1177/0040573613495230

Muthengi, J., 1998, 'The work and worship of the Christian church', in S. Ngewa, M. Shaw \& T. Tienou (eds.), Issues in African Christian theology, pp. 28-40, East Africa Educational, Nairobi.

Ndou, M.R., 2000, The Gospel and Venda culture: An analysis of factors which hindered or facilitated the acceptance of Christianity by the Vhavenda, University of Pretoria, Pretoria.

Newbigin, L., 1984, 'Cross-currents in ecumenical and evangelical understandings in mission', International Bulletin of Missionary Research 6(4), n.p.

Ngada, N.H. \& Mofokeng, K., 2001, African Christian witness: African Indigenous churches, Cluster, Pietermaritzburg.

Nicolson, R., 1990, A Black future? Jesus and salvation in South Africa, SCM, London.

Niehaus, I., 2009, 'Leprosy of a Deadlier kind: Christian conceptions of AIDS in the South African Lowveld', in F. Becker \& P.W. Geissler (eds.), AIDS and religious practice in Africa, pp. 309-332, Brill, Leiden.

Nürnberger, K., 2007, 'Ancestor veneration in the church of Christ?', Journal of Theology for Southern Africa 129, 54-69.

Nussbaum, S., 1987, 'A biblical narrative approach to strengthening the Christology of independent churches in Lesotho', in D.A. Shank (ed.), Ministry of missions to African independent churches: Papers Presented at the Conference on Ministry to AlCs, July 1986 Abidjan, Cote d'Ivoire, n.p., Mennonite Board of Missions, Elkhart, IN.

Olowola, C., 1998, 'An introduction to African independent churches', in S. Ngewa, M. Shaw \& T. Tienou (eds.), Issues in African Christian theology, n.p., East Africa Educational, Nairobi.

Oosthuizen, G.C., 1999, 'The AIC and the modernisation process', in C.W. Du Toit \& N.H. Ngada (eds.), Hearing the AIC-voice, n.p., UNISA, Pretoria.

Otijele, P.Y., 1991, 'Understanding the African worldview: A religious perspective', Ogbomoso Journal of Theology 6, 1-16.

Payne, D.F., 1994, '1 and 2 Samuel', in D.A. Carson, R.T. France, J.A. Motyer \& G.J. Wenham (eds.), New bible commentary, pp. 296-333, IVP, Downers Grove, IL.

Piper, J., 2003, Let the nations be Glad, Baker, Grand Rapids, MI.

Prill, T., 2015, 'The Gospel on the mission field', Haddington House Journal 17, 137-155.

Rankin, J. \& Stetzer, E., 2010, Spiritual warfare and missions: The battle for God's glory among the nations, B\&H, Nashville.

Reisinger, E.C., 1982, Today's Evangelism: Its message and methods, Craig, Phillipsburg.

Ribbens, B., 2011, 'Typology of types: Typology in dialogue', Journal of Theological Interpretation 5(1), 81-96.

Scarborough, D., 2013, 'World evangelization or world transformation?', Protestant Reveille 68, 1-12.

Schutz, S., 2009, 'The truncated Gospel in modern evangelicalism: A critique and beginning reconstruction', Evangelical Review of Theology 33(4), 292-305.

Shabangu, A., 2005, 'The Gospel embodied in ATR and culture with specific reference to the cult of ancestor veneration and the concept of salvation: An inculturation hermeneutic', DTh thesis, University of Pretoria, Pretoria

Shields, N., 1998, Into all the world: What the Bible teaches about mission, Bryntirion, Bridgend.

Sire, J.W., 1977, The universe next door, IVP, Leicester.

Snyder, H.A., 2011, Salvation means creation healed: The ecology of Sin and Grace: Overcoming the divorce between earth and heaven, Cascade, Eugene.

Taylor, W.D., 1986, 'The cry for justice and liberation', in R.E. Coleman (ed.), Evangelism on the cutting edge, pp. 59-74, Fleming H Revell, Old Tappen.

Trapnell, D.H., 1996, 'Health, disease and healing', in I.H. Marshall et al. (eds.), New bible dictionary, pp. 448-456, IVP, Leicester.

Van der Walt, B.J., 2005, A shame versus a guilt-oriented conscience: An explanation for the difference between African and Western Ethics, The Institute for Contemporary Christianity in Africa, Potchefstroom, pp. 1-16.

Wright, C., 2010, The mission of God's people: A biblical theology of the Church's mission, Zondervan, Grand Rapids. (Biblical Theology for Life series).

Yung, H., 2007, 'World-view', in J. Corrie (ed.), Dictionary of missionary theology, pp. 438-441, IVP, Nottingham. 